\title{
Requirements for a Psychosexual Pathway and Components of Pathways
}

Many highlight the advantage of robotic surgery in improving cancer cure rates and side effects such as erectile function [1,2]. This is a known fact [3]. Others examine the role of medical therapy, tablets, to help gain better erections after surgery [4]. Other papers argued this is interdisciplinary work [5], to be conducted by urologists alike. However, psychotherapy has also been found to be central to sexual rehabilitation [6]. Harris et al. [7] went so far as to suggest penile rehabilitation programmes for these patients. The research team is in complete agreement.

\section{References}

1. Whelan P, Ekbal S, Nehra A. Erectile dysfunction in robotic radical prostatectomy: outcomes and management. Indian Journal of Urology. 2014;30:434-42.

2. Hagen S, Glazener C, Boachie C, Buckley B, Cochran C, Dorey G, Grant A, McDonald A, McPherson G, Moore K, N'Dow J, Ramsay C. Urinary incontinence and erectile dysfunction after radical prostatectomy: association with route and technique of operation. Int Urogynecol J Pelvic Floor Dysfunct. 2010;21:S25-7.

3. Barnett C, Kumar P, Challacombe B, Dasgupta P. Robot assisted laparoscopic prostatectomy. Striving for Trifecta outcomes in localised prostate cancer. Minerva Med. 2011;102:333-8.

4. Bannowsky A, Schulze H, Uckert S, Junemann KP. Rehabilitation of erectile function two years after nerve-sparing radical prostatectomy: is there a real significant effect with nightly low-dose sildenafil (25 mg)?. [German]. J Urol Urogynakol. 2014;21:16-21.

5. Blanco Lanzillotti T. Plan for sexual function rehabilitation post radical prostatectomy (interdisciplinary work). J Sex Med. 2014;11:247.

6. Naccarato AMEP, Souto SC, Moreira M, Heckler P, Ferreira U, Souza EAP, Denardi F. Effects of phosphodiesterase inhibitors on erectile function and performance, and impacts of psychotherapy on the quality of life of patients submitted to radical prostatectomy for prostate cancer. J Sex Med. 2014;11:244.

7. Harris CJ, Anderson CB, Dietrich MS, Barocas DA, Chang SS, Cookson MS, Smith JA Jr, Clark PE, Herrell SD, Kaufman MR. Recovery of erectile function after radical prostatectomy: identification of trajectory cluster groups. J Urol. 2014;1:e337. 